the fossils with those of the ordinary coal fossils, that your coal also belonged to the Carboniferous beds. . . . Murchison clearly thinks it impossible for the fossils of the carboniferous coal field to occur below his Dudley (that is, Silurian) beds".

Sedgwick, at this period, agreed with de la Beche, and wrote that he had always supposed the Devon anthracite to be in the Greywacke, and was not surprised to learn that the plants were identical with coal-measure fossils. He concluded by saying: "The fossillogists are going Mad. The foundation of our Conclusions .. . must ever rest on the evidence of superposition, given by actual sections. Our friend Murchison has examined an astonishingly fine series of upper fossiliferous greywacke, and finding no coal plants in it, resolved in his own mind that the said plants should not be found in it anywhere else."

The note read at the meeting of the British Association was followed up by a paper read before the Geological Society in 1837, and in the meantime the matter had given rise to much discussion. Lyell, who had succeeded Greenough as president of the Society, had written to de la Beche, asking him to re-consider his position. Among other things he said : "In any district of much disturbed strata the admission of such an anomaly as the identity of the vegetation of two very remote eras on any grounds which were stated seems to me unphilosophical. . . . If you are prepared to say you have changed your mind, pray give me the opportunity of saying it on your authority in my speech."

All this shows that neither Murchison nor Lyell wished to take an unfair advantage of de la Beche ; it simply means that they thought he had made a mistake, and said so in the proper place for such views to be expressed.

Unfortunately, de la Beche was working so far away from London that he had few opportunities for meeting kindred spirits, and he was often, as his letter to Colby suggests, physically tired. Moreover, as the owner of plantations in Jamaica, he had suffered as a result of propaganda connected with the slave trade, which, in the words of Caroline Fox, had given him a "low view of mankind". In the circumstances, it is not surprising that he should have imagined the worst when he received Colby's letter, and learnt that he was being criticized in geological circles.

Although in a half-hearted way de la Beche eventually adopted the identification of the Culm proposed by Sedgwick and Murchison, there are passages in the report which indicate that he was not really convinced that the evidence of fossils could be regarded as determinative, when the field evidence appeared to point to some other conclusion-all of which goes to show the danger of dogmatism when scientific principles are under discussion.

In the controversy to which this note relates, we find doubt being cast upon a principle that Robert Hooke had conceived towards the end of the seventeenth century, that William Smith had enunciated towards the end of the eighteenth, and that is now recognized as the foundation of modern geology: namely, that the assemblage of fossils in a given series of strata is peculiar to rocks of that age, so that strata can be identified by the fossils which they contain.

1 NATURE, 143, 254-5 (1939). The present note, also, is based upon manuscripts deposited in the National Museum of Wales by the late Colonel J. I. D. Nicholl of Merthyr Mawr.

\title{
The Study of Animal Behaviour
}

$\mathrm{T}^{\mathrm{H}}$ HE study of animal behaviour has a long and arduous history. It cannot, however, be claimed that either the scope of the subject, or its methods, have been clearly defined. In interest it ranges from the ecological facts of the interaction of animals and their environments, through the details of life-history and their physiological analysis, on to questions of perception, motivation, learning and adaptive behaviour. Its methods embrace those of the field-worker, those of the physiologist, and those of the psychologist. Its philosophy, again, is in some quarters undefined, in others aggressively, even if vaguely, teleological and organismic, and elsewhere frankly empiricist. With all this diversity, those outside the subject can scarcely regard it as more than a concatenation of discrete interests and different methods. For the same reason, those within it can scarcely be blamed if their activities cover but a very narrow part of the whole subject. Nevertheless, ever since the turn of the century attempts have been made, in societies and journals abroad, to integrate what is, after all, a distinct, even though very wide, field of scientific exploration.

Great Britain has not been to the fore in this work. Indeed it was only three years ago that a society relating to the subject was founded here for the first time. This society, the Institute for the Study of Animal Behaviour, has as its aims "to promote the study of animal behaviour, to encourage the undertaking of research and the publication of the 
results of research in this field", and to carry on any further activities which it may from time to time regard as furthering these objects. It publishes a Bulletin which is devoted to reviews of recent advances in the study of animal behaviour, and it also provides research grants to investigators. Occasionally, too, it holds meetings, and it was at one of these meetings, held on June 13 in conjunction with the Zoological Society of London, that Dr. Julian Huxley briefly outlined the aims of the Institute, of which he is president, in the opening remarks to a symposium which dealt with modes of analysis of animal behaviour.

The topics considered in this symposium were perception, motivation, instinct, learning and memory, and in some measure at least the discussion thus emphasized the main compartments of animal psychology. Perception is of primary importance at every level of behaviour. It is the starting point of the responses which animals are constantly making to changes in their immediate surroundings. The methods by which it needs to be analysed are as varied as the forms which it can take. Vision, for example, has to be studied in terms of brightness-discrimination and form and colour perception; and apart from the mere statement of the kind of vision possessed by any given animal, the problem has to be explored from the point of view of the anatomical and physiological mechanisms which subserve these functions -mechanisms which are by no means necessarily the same in different species. Auditory acuity, tactile and thermal sensitivity, to mention just a few other perceptual modalities, each requires its own comprehensive mode of analysis. The particular perceptual problem dealt with at the symposium-insect communication-showed clearly how complicated a process of analysis can be, and how much the perceptual world of one animal may differ from another.

Some insects, as Dr. A. F. Rawdon-Smith pointed out, can discriminate between sounds which differ by a factor other than intensity. Quite clearly they discriminate the quality of a given sound by a process altogether different from human frequency discrimination. For example, a virgin female cricket will react to a telephone that is transmitting the chirruping of a male even when the sound is so distorted as to be unrecognizable to the human ear. Since no insect possesses a cochlea which could subserve harmonic analysis, the only possible basis of discrimination is that different sound qualities produce afferent impulses of different temporal pattern in the auditory nerves. But here, as Dr. Rawdon-Smith explained, a major difficulty is encountered. Owing to the refractory period of the nerve fibres, it is to be expected that they would discriminate only low frequencies, whereas in fact study of the passage of impulses shows that the auditory receptors of insects are incapable of responding to such frequencies and react only to frequencies of much higher magnitude. The solution to this problem was obtained by means of a carefully designed physiological experiment carried out by Dr. R. J. Pumphrey and Dr. Rawdon-Smith. It was found that the high frequencies given out by stridulating insects are carriers for a low-frequency modulation. High-frequencies themselves have no 'meaning' to insects. Their function is to carry the low-frequency modulation, and it is the latter which characterizes sound to the animal. The mechanism of auditory perception in insects is thus much less akin to that in man than it is to wireless telephony.

Dr. Rawdon-Smith's exposition was an eloquent demonstration of the possibilities of analysis of perception, and of the immense field that awaits exploration. No animal's perceptual world can be regarded a priori as being the same as another's. Things which are significant in one world may not be perceived in another, and each perceptual world presents its own problems of organization. The latter have been closely studied, particularly by Gestalt psychologists and philosophers, but while the primary issues have at times been obscured by generalities, the actual facts regarding different perceptual worlds in the animal kingdom have always remained the central problem of students working in this field of animal behaviour.

This has not always been the case with animal motivation, for here general issues have frequently obscured definite problems. The study of animal motivation is concerned with the central and peripheral nervous organization which makes response possible, and with the working of this nervous apparatus; with the analysis of other influences, for example hormonal factors, which affect behaviour; and with the definition and measurement of the various 'drives' for the fulfilment of which animals strive. The latter has been a fruitful field of experimental psychological exploration. The investigation of the part played by hormones has also yielded facts of great interest, even though the actual manner in which hormones affect behaviour has not been elucidated as yet. On the other hand, the neurological aspect of the problem has been left mainly in the hands of anatomists and physiologists, in spite of the fact that the fundamental issues of nervous physiology must form the primary facts of a study of behaviour. That they do has, of course, been generally admitted by students of behaviour, but in so far as they have not been immediately concerned in this field of study, animal psychologists have been content to base general theories of behaviour on concepts derived, for example, from the field of 
reflex physiology. The rigid 'behaviourism' of Watson was one such general theory. While it did much to organize knowledge of behaviour and to attract attention to the subject, it was far too static in its formulation to survive in the face of a growing volume of facts. Its history, too, exposes the danger of a general theory being so formulated that it does not take into account the possible changing nature of the ideas on which it is based.

This issue was vigorously dealt with by $\mathrm{Mr}$. J. Z. Young, who compared the incorrect conception of a reflex system as something which operates whenever its afferent side is stimulated, with a reflex system in which an afferent impulse becomes effective only when the motor neurons of the system are in a particular state of excitability due to impulses reaching them from other neurons with which they are in synaptic connexion. $\mathrm{He}$ went on to consider the importance of the fact that the higher nervous centres are in constant activity. For example, in cephalopods the anatomical arrangements are such that certain combinations of afferent stimuli can set in action self-re-exciting chains of neurons, the continued activity of which facilitates certain pathways. His suggestion is that the setting-up of such activities may constitute the change which takes place in a nervous system during the process of learning. Mr. Young's paper made it perfectly clear that the old analogy of the nervous system as a static telephone exchange which passes on messages to the relevant motor neurons must give way to a conception of an exchange always in active change itself.

Although general theories of behaviour that are based upon neurological concepts may even yet be inadequate, they are much more valuable to animal psychology than discussions as to the reality of concepts such as instinct. Dr. J. A. Loeser's contribution to the symposium, which was substantially the same as an article of his published in NaTURE of May 27, p. 880, was concerned with this question, and unfortunately his attempt to banish the concept in favour of even less tangible concepts of behaviour cannot be regarded as a successful one. Dr. Loeser's main point is that every organic action represents merely the satisfaction of an impulse, and that in so far as no response of an animal can have any conscious or unconscious relation to self- or race-preservation, it cannot be an instinctive action; therefore there is no such thing as instinct. A hen, for example, does not sit on eggs because she wishes to hatch the next generation of hens, but because sitting on cool curved objects soothes irritating surfaces of her body. This may all be very true, but the fact remains, as Dr. Loeser admits, that whatever the basis of so-called instinctive behaviour, subjective aims and objective purposes often appear to coincide. The argument is purely one of definition. Instinct is widely defined as that faculty, other than a rational process, which makes inborn animal behaviour seem purposive. As Prof. Lashley effectively argues in a recent article, "the antiinstinct movement was aimed primarily as the postulation of imaginary forces as explanations of behaviour". It scarcely helps the subject to dismiss the presumed hereditary basis of instinct, and to continue talking, as Dr. Loeser does, about the "psyche and consciousness", or the "genuine risk and genuine reflection" of behaviour.

Fortunately, the learning processes and adaptive behaviour of animals lend themselves to a more satisfactory type of generalization than the unlearned reactions which usually go by the name of instinct. The literature on this question is extensive, and the experimental work which is being carried out is as a rule sufficiently well designed to allow of the constant re-testing of the general theories of learning which have been derived from previous studies. An excellent example was given by Mr. G. C. Drew in his contribution to the symposium. One of the wellknown theories of learning is the Law of Effect, which states that reactions which are rewarded tend to be stamped in, while those which are punished tend to be eliminated. This hypothesis has been thoroughly substantiated so far as rewards are concerned, whereas recent work has thrown considerable doubt on the part which punishment is supposed to play in the process of learning. Indeed, work by Drew and others has shown that where an electric shock is the punishment in experiments on rats, a mild shock has an equally facilitative effect on the speed of learning whether it be given for the wrong response or for the correct response, whether it be associated with both types of response, or whether it be associated with the reward.

Experiments of this kind are still not as numerous as they might be, nor as consistent with each other as is to be desired, but they are representative of an approach in the analysis of behaviour which is truly fruitful. So, too, were the experimental studies on delayed reaction and memory reviewed by Dr. S. Zuckerman. These concerned the ability of animals to make a discrimination between an incorrect and a correct stimulus when their responses are separated from their perception of the problem by intervals of varying length. Other experiments which were described dealt with the observation that chimpanzees can be taught to regard disks of various sizes and colours as symbols for specific foods. The fact that the animals will work for these disks, fight or beg for them, and hoard them, even if it 
be only for a day, until they have the opportunity of exchanging them for the foods they represent, raises a considerable question from the point of view of the genesis of abstract and symbolic behaviour.

If it succeeded in nothing else, the symposium undoubtedly did indicate to those who were present the vast field of interest which can be defined under the term 'animal behaviour'. It is clearly impossible for any one science to deal with all aspects of this subject. This very fact is one of the best arguments for the existence of an organization, such as the Institute for the Study of Animal Behaviour, prepared to undertake the task of integrating the numerous studies, carried out in different departments of science, which are related under the heading 'animal behaviour'. The task that lies before the Institute is, however, far more than just the reviewing of separate advances in the subject, for this activity cannot but lead to the more responsible one of indicating the lines along which research needs to be directed.

\section{Obituary Notices}

\section{Dr. Jan Koliha}

The National Museum of the Kingdom of Bohemia, at Prague, has suffered an irreparable loss in the untimely death of Dr. Jan Koliha, head of the Palæontological Department of the museum since 1931.

Dr. Koliha was born on May 3, 1890, at Police nad Metuji in Eastern Bohemia, where his father was a teacher. $\mathrm{He}$ had already begun collecting natural history specimens in his teens, and when he proceeded to the Charles University of Prague, in about 1900, he studied natural science and obtained the degree of Ph.D. for a dissertation on "The Atremata of the Krušná Hora Beds" (published in Palceontographica Bohemice).

Koliha next became assistant in geology and mineralogy to Prof. Cyril Purkyne at the Technical University, and also at the National Museum under Prof. Perner. The latter advised him to abandon his studies of the Bohemian Cretaceous and devote himself to the Palæozoic strata of his country, which are well represented to the south and south-west of Prague.

While still a student Koliha had made the acquaintance of the great zoologist and palæontologist Prof. Antonín Frič, who died in 1913. Frič lived to see the collections of the National Museum removed to the fine buildings at the top of Wenceslas Square (1892). Here Dr. Koliha, together with the late Dr. J. S. Procházka, acted as assistant to Prof. Kafka. On the death of the latter (1929), Dr. Procházka became the head of the Palæontological Department until his death in 1931, when Koliha succeeded him. From this year the galleries containing Barrande's collections were called the Barrandeum, and Koliha was given the title 'Custodian of the Barrandeum'. He likewise became responsible for all the palæontological collections, with the exception of fossil plants, which were under the care of Dr. Nermejc.

Dr. Koliha was the chief authority on the Lower Palæozoic fossils of Bohemia. $\mathrm{He}$ is especially to be remembered for his research on the Tremadocian of Eastern Bohemia (1925). Drs. Kodym and Matējka of the State Geological Survey had found black clay shale near Ceský Brod (East Bohemia) in a locality hitherto supposed to be Cretaceous. Dr. Koliha examined some of the material and on the basis of the contained fossils proved it to be of Lower Ordovician age. Later he succeeded in correlating it with the Tremadoc Shales. An account of this discovery is given in the Journal of the State Geological Institute of C.S.R., vol. 2, pp. $305 \mathrm{ff}$. The importance of this discovery was shown by the fact that it placed the Ordovician fauna of Eastern Bohemia in quite another sea to that which existed in the Barrandian basin at the same time. The Tremadocian of East Bohemia belongs to the Baltic-Scandinavian facies.

Dr. Koliha was well known and honoured not only in his own country, but also in Great Britain, Germany, Sweden, and the United States. As a specialist in the older Palæozoic he was unrivalled, and material from all over the world came to him for determination. He was likewise a good zoologist. He possessed a surprising knowledge of English literature. $\mathrm{He}$ was also acquainted with Swedish and Welsh, and spoke excellent French.

Dr. Koliha was a kind friend and a good colleague. He was for many years a member of the Geographical Society of Prague, of the Geological and Mineralogical Society of Czechoslovakia and also of the National Museum Society, to the meetings of which he contributed many inspiring lectures and other communications on palæontological matters. He died on April 7, after long suffering. His place at the Museum has been taken by his colleague Dr. Nermejc.

I am indebted to Prof. Perner of the Charles University and to Dr. F. Prantl, of the National Museum, for some of the details of Dr. Koliha's work and career.

T. OAKes Hirst.

WE regret to announce the following deaths :

Dr. E. T. S. Appleyard, research assistant in physies in the University of Bristol, on June 15, aged thirty-five years.

Prof. A. E. Kennelly, emeritus professor of electrical engineering in Harvard University and the Massachusetts Institute of Technology, on June 18, aged seventy-seven years.

Dr. E. Kidson, O.B.E., director of meteorological services in New Zealand since 1927, aged fifty-seven years. 